\title{
Kartu Indonesia Pintar sebagai Representasi No Poverty dan Education dalam paradigma Sustainable Development Goals
}

\author{
Ahmad Fajar Rahmatullah ${ }^{1}$ \\ Fakultas Ilmu Sosial dan Ilmu Politik, Program Studi Ilmu \\ Pemerintahan, Universitas Muhammadiyah Yogyakarta, \\ Indonesia \\ fajarrahmatullah.a@gmail.com
}

\begin{abstract}
Ahmad Farhan Rahmatullah ${ }^{2}$
Fakultas Hukum, Program Studi Ilmu Hukum, Universitas Muhammadiyah Yogyakarta

ahmad.farhan.law20@mail.umy.ac.id
\end{abstract}

\author{
E-ISSN 2721-0642 \\ Article Info \\ Recieved: \\ August 272021 \\ Revised: \\ November 32021 \\ Accepted: \\ December 122012 \\ Doi Number \\ https://doi.org/10.37950/ijd.v3i3.110
}

\begin{abstract}
Sustainable Development Goals (SDGs) is a concept of sustainable development combines aspects of social, economic and environmental 17 sustainable development Goals where the first point is No poverty or no poverty. No poverty to be the first point in the SDGs indicates that all the Countries that signed the Document of the SDGs agreed to see the problem of poverty became a serious problem that must be handled by all Countries in the world. To eradicate poverty of course, every Country has her way each. Interesting things seen in the program which is run by the government of President Jokowi in terms of the alleviation of poverty by through education. The concept of no poverty by way of education is not a new thing. This study uses the study of a literature review with a focus on the study of how the government program in the fight against poverty through education. This study resulted that the efforts to alleviate poverty through education has been run by the Government of Joko Widodo in the period from the first through the Indonesia Smart Program whereby in the year 2015 until the year 2019 poverty significantly decreased and the school participation rate (APS) is increased. In addition have implemented the goals of the first SGD is no poverty, the government of Joko Widodo also indirectly apply goals to 4, namely Quality Education in Indonesia Smart Program.
\end{abstract}

Keywords : sustainable development goals; no poverty ;education; kartu indonesia pintar. 


\begin{abstract}
Abstrak
Sustainable Development Goals (SDGs) merupakan sebuah konsep pembangunan yang berkelanjutan mengkombinasikan aspek sosial, ekonomi serta lingkungan dengan 17 Tujuan pembangunan berkelanjutan dimana point pertama adalah No poverty atau tanpa kemiskinan. No poverty menjadi point pertama dalam SDGs mengindikasikan bahwa seluruh Negara yang menandatangani Dokumen SDGs sepakat melihat permasalahan kemiskinan menjadi masalah yang serius yang harus di tangani oleh seluruh Negara di dunia. Dalam memberantas kemiskinan tentunya tiap Negara memiliki cara nya masing-masing. Hal menarik terlihat dalam program yang di jalankan oleh pemerintah Presiden Jokowi dalam hal pengentasan kemiskinan dengan cara melalui pendidikan. Konsep pemberantasan kemiskinan dengan cara pendidikan bukan merupakan hal yang baru. Studi ini menggunakan studi literatur dengan fokus studi tentang bagaimana program pemerintah dalam upaya pengentasan kemiskinan melalui pendidikan. Studi ini menghasilkan bahwa upaya pengentasan kemiskinan melalui pendidikan telah dijalankan oleh Pemerintahan Joko Widodo pada periode pertamanya melalui Program Indonesia Pintar dimana pada tahun 2015 hingga tahun 2019 kemiskinan secara signifikan menurun dan angka partisipasi sekolah (APS) meningkat. Selain telah menerapkan goals pertama SGD yaitu no poverty, disamping itu pemerintahan Joko Widodo juga secara tidak langsung menerapkan goals ke 4 yaitu Quality Education pada Program Indonesia Pintar.
\end{abstract}

Kata kunci: sustainable development goals; kemiskinan; pendidikan; kartu indonesia pintar.

\title{
Pendahuluan
}

Konsep Pembangunan berkelanjutan atau yang biasa disebut dengan Sustainable Development Goals telah menjadi konsep yang populer dan menjadi fokus seluruh dunia internasional dimana dapat mengakomodasikan segala perubahan yang terjadi mengenai isu sumber daya alam yang menipis, lingkungan yang mengalami kerusakan, iklim yang terus berubah, jaminan perlindungan sosial, ketahanan pangan dan energi serta menjadi arah pembangunan yang lebih berpihak kepada kaum miskin (Crespo Cuaresma et al., 2018; Fauzi \& Oxtavianus, 2014; Florini \& Pauli, 2018; Sutopo et al., 2014). Konsep ini pertama kali diperkenalkan pada bulan september 2015 di New York Amerika Serikat dimana Perserikatan Bangsa-Bangsa (PBB) melakukan sidang umum yang ke 70 dihadiri oleh Kepala Negara serta Pemerintahan dari 193 negara di dunia menyepakati agenda pembangunan universal baru tertuang di dalam dokumen yang berjudul "Transforming Our World: the 2030 Agenda for Sustainable Development" berisi 17 Tujuan serta 169 sasaran yang berlaku pada tahun 2016 hingga 2030, dokumen ini dikenal dengan istilah Sustainable Development Goals (SDGs) (United Nation, 2015).

Pembangunan berkelanjutan diartikan sebagai sebuah pergerakan sosial oleh sekelompok orang dengan ideologi yang sama untuk mencapai tujuan yang di inginkan untuk dapat memenuhi kebutuhan pada masa kini sekaligus menjaga sistem pendukung kelangsungan kehidupan bumi sebagai sandaran kesejahteraan untuk 
generasi sekarang dan generasi mendatang pada akhirnya dapat membantu mengarahkan dunia menuju arah yang berkelanjutan (Erlinda, 2016; Grigss, 2013; Kates et al., 2005; Sachs, 2012; Wibisana, 2017). Pembangunan berkelanjutan dimaknai sebagai pembangunan yang bersifat sosial, dimana pembangunan tersebut dapat memenuhi kebutuhan generasi saat ini tanpa mengurangi kemampuan generasi yang akan datang dalam memenuhi kebutuhannya menuju kesejahteraan (Jayanti, 2017; Nababan et al., 2014).

Pembangunan berkelanjutan diartikan sebagai pembangunan yang tidak hanya memberikan persamaan atas hak-hak mendasar, tetapi juga memberikan perlindungan pada mereka yang paling tidak beruntung, baik yang hidup pada generasi sekarang maupun generasi yang akan datang (Wibisana, 2017). Ada tiga pilar yang menjadi indikator dalam konsep pengembangan SDGs yaitu, pertama indikator yang melekat pembangunan manusia (Human Development), di antaranya pendidikan, kesehatan. Indikator kedua yang melekat pada lingkungan kecilnya (Social Economic Development), seperti ketersediaan sarana dan prasarana lingkungan, serta pertumbuhan ekonomi. Sementara itu, indikator ketiga melekat pada lingkungan yang lebih besar (Environmental Development), berupa ketersediaan sumber daya alam dan kualitas lingkungan yang baik (Wahyuningsih, 2017).

Pembangunan berkelanjutan (SDGs) menyangkut aspek multidimensi dari sisi ekonomi, sosial, dan lingkungan dengan masing-masing ukuran atau indikator yang berbeda dimana memerlukan pertimbangan yang simultan dari berbagai aspek untuk dapat berhasilnya implementasi pembangunan berkelanjutan yang diwujudkan dalam ukuran keadilan, kenyamanan dan kelestarian (Cinelli et al., 2014; Niken Pratiwi, Dwi Budi Santosa, 2018; Poveda \& Lipsett, 2011; Shmelev \& Labajos, 2009). Hal senada menurut Rahmatullah (2020) mengatakan bahwa tujuan pembangunan menghendaki terlaksananya berbagai aktivitas pembangunan yang terarah dan berlandaskan suatu pedoman yang dapat memberikan arahan, strategi, serta dasar dari suatu kebijakan untuk dapat melaksanakan pembangunan.

Dalam 17 Tujuan Sustainable Development Goals oleh United Nation (2015), point pertama menyatakan bahwa No Poverty artinya tanpa kemiskinan, tidak ada kemiskinan dalam bentuk apapun di seluruh dunia menjadi point prioritas yang bermakna bahwa seluruh dunia telah sepakat untuk meniadakan kemiskinan dalam bentuk apapun, tanpa terkecuali Indonesia. hal tersebut sesuai dengan apa yang di katakan oleh Florini \& Pauli (2018) bahwa Konsep SDG disahkan sebagai tolak ukur yang telah disepakati secara global dalam pembangunan yang berkelanjutan serta berpihak pada orang miskin. 
Gambar 1. Sustainable Development Goals 1 (No Poverty)

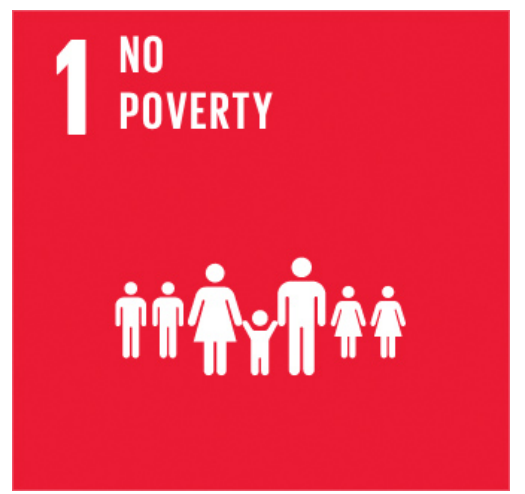

Sumber: United Nation (United Nation, 2015)

Salah satu tujuan dari pembangunan adalah menurunkan angka kemiskinan. Kemiskinan merupakan masalah kompleks yang dipengaruhi oleh berbagai faktor yang saling berkaitan, antara lain: tingkat pendapatan, pendidikan, akses terhadap barang dan jasa, lokasi geografis, gender dan kondisi lingkungan (Amaliah, 2015). Kemiskinan merupakan permasalahan yang mendasar dalam pembangunan ekonomi, terutama pada negara berkembang seperti Indonesia. Kemiskinan didefinisikan sebagai ketidakmampuan seseorang dalam memenuhi kebutuhan dasarnya karena ketidakberdayaan dalam mengakses atau menguasai sumber-sumber ekonomi (Nur, 2014).

Table 1. Persentase Kemiskinan Di Indonesia (2015-2019)

\begin{tabular}{|l|l|l|}
\hline Semester & Tahun 2015 (\%) & Tahun 2019 (\%) \\
\hline 1 (Maret0 & 11,22 & 9,41 \\
\hline 2 (September) & 11,13 & 9,22 \\
\hline \multicolumn{1}{|c|}{ Sumber: Pusat } & Statistik
\end{tabular}

(https://www.bps.go.id/dynamictable/2016/08/18/1219/persentase-penduduk-miskin-menurutprovinsi-2007---2019.html) dioleh oleh penulis

Menurut Ustama (2010) Kemiskinan adalah suatu kondisi di mana seseorang atau suatu kelompok baik laki-laki atau perempuan tidak bisa mendapatkan hak mereka untuk bertahan hidup dan mengembangkan martabat manusianya, salah satu solusi untuk menghilangkan kemiskinan adalah melalui pendidikan yang mana dapat mengembangkan modal manusia mereka. Herlina (2014) juga menyatakan bahwa kemiskinan dan pendidikan adalah dua aspek yang memiliki kaitan sangat erat apabila digabungkan dengan kesejahteraan yang ada di masyarakat. Hal yang sama menurut Rohaeni \& Saryono (2018) menyatakan bahwa kemiskinan menyebabkan terbatasnya terbatasnya masyarakat untuk mengakses pendidikan, sedangkan pendidikan 
bertujuan untuk membantu masyarakat keluar dari jeratan kemiskinan yang mereka hadapi.

Terkait dengan masalah pendidikan, hal itu sejalan dengan tujuan yang ada di dalam Sustainable Development Goals (SDGs) sebagai pedoman pembangunan yang telah di tanda tangani oleh 193 Negara termasuk Indonesia. SDGs sebagai sebuah pedoman, tentu sangat berhubungan dengan hak dasar pemenuhan warga (right based approach) yang dapat dilihat berdasarkan Human Development Index yang mencerminkan sejauh mana negara mampu memenuhi hak-hak dasar warga negaranya. Tentu hal ini pun sejalan dengan Tujuan SDGs goals 4 Quality Education Pendidikan Berkualitas Menjamin Kualitas Pendidikan yang Inklusif dan Merata serta Meningkatkan Kesempatan Belajar Sepanjang Hayat untuk Semua pada tahun 2015 yang mentargetkan pendidikan untuk semua.

Gambar 2. Sustainable Development Goals 4 (Quality Education)

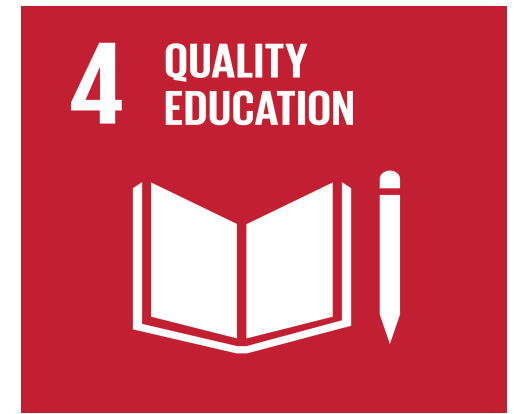

Sumber : United Nation (2015)

Penelitian terdahulu banyak yang membahas tentang kemiskinan dan hubungannya dengan pendidikan. Menurut Arius (2012) menjelaskan bahwa melek huruf berkorelasi negatif dan signifikan terhadap kemiskinan di Indonesia. Melek huruf dapat dimaknai sebagai kemampuan untuk menjalin hubungan dengan orang lain melalui pembicaraan, membaca, dan menulis, yang diaplikasikan pada kemampuan untuk memanfaatkan media massa dan berbagai teknologi informasi. Tujuan dari melek huruf adalah peningkatan taraf kehidupan masyarakat, keikutsertaan publik, penyelesaian masalah kemanusiaan, dan perluasan kapasitas individu dan sosial masyarakat. Konsep tentang melek huruf menunjukkan adanya hubungan antara tingkat kemampuan baca tulis dan partisipasi sekolah dengan kemiskinan. Konsep tersebut juga menunjuk pada kepemilikan dan kemampuan mengelola informasi melalui media dan teknologi komunikasi dengan kemiskinan dan masalah-masalah sosial yang lain.

Rendahnya produktivitas tenaga kerja kaum miskin dapat disebabkan oleh karena rendahnya akses mereka untuk memperoleh pendidikan. Pada akhirnya seseorang yang memiliki produktivitas yang tinggi, selain itu diketahui juga bahwa lama pendidikan penduduk berkorelasi negatif dan signifikan terhadap kemiskinan di Indonesia. Taraf pendidikan yang rendah yang tercermin dari lama pendidikan yang rendah mengakibatkan kemampuan pengembangan diri yang terbatas dan menyebabkan sempitnya lapangan kerja yang dapat dimasuki sehingga kemiskinan 
tetap merajalela. Penduduk yang hidup di bawah garis kemiskinan memiliki akses yang terbatas terhadap pendidikan, sehingga kualitas sumber daya manusianya menjadi rendah pula yang menyebabkan produktivitasnya juga rendah, sehingga penghasilan mereka menjadi juga rendah. Jadi, dengan meningkatkan kualitas sumber daya manusia maka akan berpengaruh terhadap pengurangan jumlah penduduk miskin.

Hal senada juga di jelaskan oleh Ustama (2010) bahwa Dengan pendidikan yang baik, setiap orang memiliki bekal pengetahuan dan keterampilan, mempunyai pilihan untuk mendapat pekerjaan, dari menjadi lebih produktif sehingga dapat meningkatkan pendapatan. Dengan demikian pendidikan dapat memutus mata rantai kemiskinan dan menghilangkan eksklusi sosial, untuk kemudian meningkatkan kualitas hidup dan mewujudkan kesejahteraan masyarakat. Dalam perspektif demikian, negara mempunyai kewajiban untuk menyediakan layanan pendidikan bagi setiap warganya, paling kurang untuk jenjang pendidikan dasar.

Dari uraian singkat diatas, pendidikan dapat dilihat sangat penting dalam peradaban manusia oleh sebab itu dalam penelitian ini memiliki tujuan untuk dapat menganalisis bagaimana kebijakan dikeluarkannya Kartu Indonesia Pintar sebagai upaya pengentasan kemiskinan dalam bidang pendidikan dalam paradigma SDG's dapat dengan tepat di implementasikan.

\section{Kerangka Teori}

Pembangunan berkelanjutan diartikan sebagai sebuah pergerakan sosial oleh sekelompok orang dengan ideologi yang sama untuk mencapai tujuan yang diinginkan untuk dapat memenuhi kebutuhan pada masa kini sekaligus menjaga sistem pendukung kelangsungan kehidupan bumi sebagai sandaran kesejahteraan untuk generasi sekarang dan generasi mendatang pada akhirnya dapat membantu mengarahkan dunia menuju arah yang berkelanjutan (Erlinda, 2016; Grigss, 2013; Kates et al., 2005; Sachs, 2012; Wibisana, 2017). Pembangunan berkelanjutan dimaknai sebagai pembangunan yang bersifat sosial, dimana pembangunan tersebut dapat memenuhi kebutuhan generasi saat ini tanpa mengurangi kemampuan generasi yang akan datang dalam memenuhi kebutuhannya menuju kesejahteraan (Jayanti, 2017; Nababan et al., 2014).

Gambar 3. The United Nations Sustainable Development Goals (SDGs)

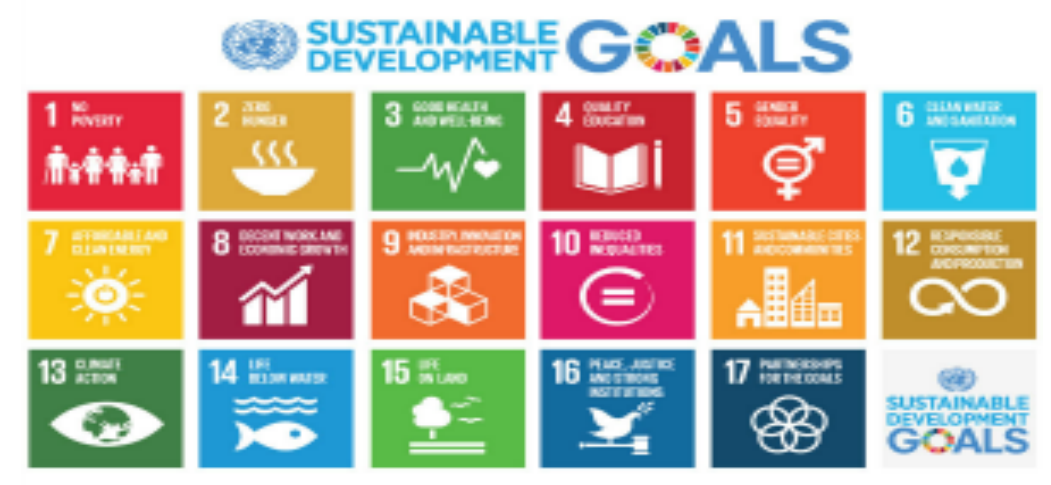




\section{Tujuan SDGs menurut United Nation (2015) yaitu :}

1) Tanpa Kemiskinan. Tidak ada kemiskinan dalam bentuk apapun di seluruh penjuru dunia. 2) Tanpa Kelaparan. Tidak ada lagi kelaparan, mencapai ketahanan pangan, perbaikan nutrisi, serta mendorong budidaya pertanian yang berkelanjutan. 3) Kesehatan yang Baik dan Kesejahteraan. Menjamin kehidupan yang sehat serta mendorong kesejahteraan hidup untuk seluruh masyarakat di segala umur. 4) Pendidikan Berkualitas. Menjamin pemerataan pendidikan yang berkualitas dan meningkatkan kesempatan belajar untuk semua orang, menjamin pendidikan yang inklusif dan berkeadilan serta mendorong kesempatan belajar seumur hidup bagi semua orang.

5) Kesetaraan Gender. Mencapai kesetaraan gender dan memberdayakan kaum ibu dan perempuan. 6) Air Bersih dan Sanitasi. Menjamin ketersediaan air bersih dan sanitasi yang berkelanjutan untuk semua orang. 7) Energi Bersih dan Terjangkau. Menjamin akses terhadap sumber energi yang terjangkau, terpercaya, berkelanjutan dan modern untuk semua orang. 8) Pertumbuhan Ekonomi dan Pekerjaan yang Layak. Mendukung perkembangan ekonomi yang berkelanjutan dan inklusif, lapangan kerja yang penuh dan produktif, serta pekerjaan yang layak untuk semua orang. 9) Industri, Inovasi dan Infrastruktur. Membangun infrastruktur yang berkualitas, mendorong peningkatan industri yang inklusif dan berkelanjutan serta mendorong inovasi.

10) Mengurangi Kesenjangan. Mengurangi ketidaksetaraan baik di dalam sebuah negara maupun di antara negara-negara di dunia. 11) Keberlanjutan Kota dan Komunitas. Membangun kota-kota serta pemukiman yang inklusif, berkualitas, aman, berketahanan dan bekelanjutan. 12) Konsumsi dan Produksi Bertanggung Jawab. Menjamin keberlangsungan konsumsi dan pola produksi. 13) Aksi Terhadap Iklim. Bertindak cepat untuk memerangi perubahan iklim dan dampaknya. 14) Kehidupan Bawah Laut. Melestarikan dan menjaga keberlangsungan laut dan kehidupan sumber daya laut untuk perkembangan pembangunan yang berkelanjutan. 15) Kehidupan di Darat. Melindungi, mengembalikan, dan meningkatkan keberlangsungan pemakaian ekosistem darat, mengelola hutan secara berkelanjutan, mengurangi tanah tandus serta tukar guling tanah, memerangi penggurunan, menghentikan dan memulihkan degradasi tanah, serta menghentikan kerugian keanekaragaman hayati.

16) Institusi Peradilan yang Kuat dan Kedamaian. Meningkatkan perdamaian termasuk masyarakat untuk pembangunan berkelanjutan, menyediakan akses untuk keadilan bagi semua orang termasuk lembaga dan bertanggung jawab untuk seluruh kalangan, serta membangun institusi yang efektif, akuntabel, dan inklusif di seluruh tingkatan. 17) Kemitraan untuk Mencapai Tujuan. Memperkuat implementasi dan menghidupkan kembali kemitraan global untuk pembangunan yang berkelanjutan (Le Blanc, 2015).

Human Development (pembangunan manusia) yaitu pendidikan dan kesehatan, Social Economic Development yaitu tersedianya sarana serta prasarana lingkungan dan 
pertumbuhan ekonomi, Enviromenmental Development yaitu sumber daya alam yang tersedia serta lingkungan dengan kualitas yang baik menjadi tiga pilar indikator penting dalam konsep SDGS (Wahyuningsih, 2017). Ada 5 pondasi utama dalam Sustainable Development Goals (SDGs) yaitu manusia, planet, kesejahteraan, perdamaian, dan kemitraan dalam menjaga keseimbangan tiga dimensi pembangunan tersebut (Raharjo, 2015).

\section{Metode Penelitian}

Penulis menggunakan metode deskriptif kualitatif. Menggunakan metode ini penulis berusaha untuk dapat mendeskripsikan, menganalisa serta membangun makna tentang fenomena yang ada Sugiyono (2013). Sementara itu, Hermawan (2019) menjelaskan bahwa penelitian kualitatif merupakan penelitian yang dilakukan dalam pengaturan tertentu yang ada dalam kehidupan nyata dengan maksud menyelidiki serta memahami fenomena dimana tujuannya untuk menyelidiki apa yang terjadi, mengapa itu terjadi dan bagaimana itu terjadi.

Pendekatan deskriptif dapat diartikan sebagai suatu cara pemecahan masalah yang diselidiki dengan menampilkan gambaran keadaan subyek atau obyek penelitian seperti individu, lembaga, kelompok dan masyarakat pada saat sekarang berdasarkan fakta yang tampak dan lain sebagainya (Nawawi, 2015). Sedangkan menurut Nazir (2013, p. 43) metode deskriptif yaitu suatu metode dalam meneliti status sekelompok manusia, suatu objek, suatu set kondisi, suatu sistem pemikiran, ataupun suatu kelas peristiwa pada masa sekarang. Tujuan dari penelitian deskriptif ini adalah untuk membuat deskripsi, gambaran atau lukisan secara sistematis, faktual dan akurat mengenai fakta-fakta, sifat-sifat serta hubungan antar fenomena yang diselidiki.

Teknik pengumpulan data menggunakan studi kepustakaan yaitu teknik pengumpulan data menggunakan berbagai literatur seperti buku, majalah, jurnal, dan laporan penelitian terdahulu. Dengan menggunakan studi pustaka diharapkan penulis dapat memperoleh informasi mengenai teknik-teknik penelitian yang akan dilakukan, dengan harapan penelitian penulis bukan hasil duplikasi. Menurut Nazir (2013, p. 79) dengan melakukan studi literatur, peneliti dapat memanfaatkan semua informasi dan pemikiran yang relevan dengan penelitian mereka.

\section{Hasil dan Diskusi}

Peran pendidikan dalam kaitannya dengan pengentasan kemiskinan telah di jelaskan oleh Jeffrey Sachs (2005) dalam bukunya yang berjudul "The End of Poverty: Economic Possibilities for Our Time" ia mengatakan bahwa salah satu mekanisme dalam upaya penuntasan kemiskinan yaitu dengan cara melakukan pengembangan human capital terutama dalam hal pendidikan. Dengan pendidikan yang baik, setiap orang memiliki bekal pengetahuan dan keterampilan, mempunyai pilihan untuk mendapatkan pekerjaan, menjadikan ia lebih produktif sehingga dapat meningkatkan pendapatan. Dengan demikian pendidikan dapat memutus mata rantai kemiskinan dan 
menghilangkan eksklusi sosial, untuk kemudian meningkatkan kualitas hidup dan mewujudkan kesejahteraan masyarakat.

Dalam perspektif demikian, negara mempunyai kewajiban untuk menyediakan layanan pendidikan bagi setiap warganya, paling kurang untuk jenjang pendidikan dasar. Bahkan Deklarasi HAM PBB 1948 tentang DEKLARASI UNIVERSAL HAK-HAK ASASI MANUSIA pasal 24 ayat 1 berbunyi "Setiap orang berhak memperoleh pendidikan. Pendidikan harus dengan cuma-cuma, setidak-tidaknya untuk tingkatan sekolah rendah dan pendidikan dasar. Pendidikan rendah harus diwajibkan. Pendidikan teknik dan kejuruan secara umum harus terbuka bagi semua orang, dan pendidikan tinggi harus dapat dimasuki dengan cara yang sama oleh semua orang, berdasarkan kepantasan".

Hal tersebut tercermin dalam Konstitusi Negara Republik Indonesia Sesuai dengan pasal 31 Undang-Undang Dasar 1945 yang mengatakan bahwa setiap warga Negara berhak mendapat dan mengikuti pendidikan dasar dan pemerintah wajib membiayai-nya. Untuk mencapai target pembangunan yang berkelanjutan (SDGs) dalam konteks pengentasan kemiskinan di bidang pendidikan, maka pemerintah Indonesia terus berupaya melakukan program pemerataan pendidikan terutama pada masyarakat yang masuk dalam kategori masyarakat miskin yang selama ini mengalami berbagai macam kendala mulai dari masalah biaya hingga dikeluarkan dari sekolah. Pemerintah berupaya melakukan peningkatan partisipasi pendidikan bagi seluruh warga Negara tanpa terkecuali sehingga hak-hak dasar mereka dapat terpenuhi sebagaimana telah di amanatkan oleh Konstitusi Undang-Undang Dasar Negara Republik Indonesia Pasal 31.

Partisipasi pendidikan sendiri di Indonesia di ukur dengan satuan APS (Angka Partisipasi Sekolah ) yang mana menunjukan dalam kurun tahun 2015 hingga 2019 usia penduduk 7-12 tahun meningkat dari 99,08 \% pada tahun 2015 menjadi 99,24 \% pada tahun 2019, sedangkan rentan usia 13-15 tahun meningkat dari 94,72\% menjadi 95,51 $\%$, rentan usia 16-18 tahun juga mengalami peningkatan dari 70,61 \% menjadi 72,36 \%, pada rentan usia 19-24 tahun meningkat dari persentase 22,95\% menjadi 25,21 \%.

Table 2. Angka Partisipasi Sekolah di Indonesia (2015-2019)

\begin{tabular}{|l|l|l|}
\hline Umur & Tahun 2015 (\%) & Tahun 2019 (\%) \\
\hline $7-12$ & 99,08 & 99,24 \\
\hline $13-15$ & 94,72 & 95,51 \\
\hline $16-18$ & 70,61 & 72,36 \\
\hline $19-24$ & 22,94 & 25,21 \\
\hline
\end{tabular}

Sumber :Badan Pusat Statistik (n.d.-a) (https://www.bps.go.id/linkTableDinamis/view/id/1054) diolah oleh Penulis.

Berdasarkan data Badan Pusat Statistik Indonesia diatas menyatakan bahwa selama tahun 2015 hingga 2019 pada semester 1 (maret) tahun 2015 hingga semester 2 (September ) tahun 2019 persentase penduduk Indonesia mengalami penurunan kemiskinan yang cukup signifikan sebesar $2 \%$. Untuk angka partisipasi sekolah untuk 
jenjang usia 7-12 tahun selama periode 2015 hingga 2019 mengalami kenaikan sebesar 0,16\%, jenjang usia 13-15 tahun mengalami kenaikan sebesar 0,76 \%, jenjang 16-18 tahun mengalami kenaikan sebesar 1,75 \% dan usia 19-24 tahun mengalami kenaikan sebesar 2,27 \% jika ditotalkan maka kenaikan angka partisipasi sekolah untuk semua usia pada tahun 2015-2019 sebanyak 1,24 \%.

Peningkatan angka partisipasi sekolah (APS) serta penurunan angka kemiskinan di Indonesia tidak terlepas dari program-program yang di lakukan oleh Presiden Joko Widodo dalam program pengentasan kemiskinan yang di jalankan-nya. Presiden Joko Widodo dalam periode pertama melakukan beberapa program pengentasan kemiskinan pada masa pemerintahan nya, adapun beberapa pengentasan kemiskinan periode pemerintahan Presiden Joko Widodo pada masa pemerintahan periode pertamanya yaitu 1)Program Indonesia Pintar, 2)Program Indonesia Sehat ,3)Program Keluarga Harapan, 4) Beras Sejahtera (Rastra) atau Bantuan Sosial Pangan, 5)Bantuan Pangan Non Tunai, 6)Program Dana Desa, dan \&Program Reforma Agraria dan Perhutanan Sosial (RAPS).

Program Indonesia Pintar dalam konteks Human Capital oleh Jefferson yang mengatakan bahwa salah satu cara pengentasan kemiskinan adalah di bidang pendidikan tampaknya sejalan dengan adanya Program Indonesia Pintar ini, Program ini merupakan salah satu prioritas pengentasan kemiskinan yang di prioritaskan oleh Pemerintahan Presiden Joko Widodo, hal itu menjadi bukti bahwa dalam menjalankan pemerintahannya, Presiden Joko Widodo berupaya mengamanatkan pasal 31 UUD Negara Republik Indonesia mengamanatkan bahwa setiap warga Negara berhak mendapat dan mengikuti pendidikan dasar dan pemerintah wajib membiayai nya. Pendidikan merupakan salah satu poin penting yang terdapat dalam Pembukaan UUD Negara RI Tahun 1945 Alinea 4. Pada alinea tersebut, pendidikan dijadikan sebagai salah satu tujuan negara Indonesia. Dasarnya terdapat pada kalimat "mencerdaskan kehidupan bangsa." Salah satu program pemerintah yang diharapkan dapat membantu siswa dalam bidang pendidikan adalah PIP melalui Kartu Indonesia Pintar (KIP). PIP adalah pemberian bantuan pendidikan secara tunai kepada anak sekolah usia 6-21 tahun yang berasal dari keluarga kurang mampu dan merupakan bagian dari penyempurnaan Bantuan Siswa Miskin (BSM). Program Indonesia Pintar diimplementasikan dalam rangka melaksanakan Kebijakan Presiden Nomor 7 tahun 2014 guna membentuk dan membangun keluarga produktif.

Program Indonesia Pintar diharapkan mampu menjamin peserta didik dapat melanjutkan pendidikan sampai tamat pendidikan menengah, dan menarik siswa putus sekolah atau tidak melanjutkan pendidikan agar kembali mendapatkan layanan pendidikan. Program Indonesia Pintar merupakan program pemerintah pusat melalui Kementerian Pendidikan dan Kebudayaan yang diluncurkan untuk mengatasi masalah pendidikan sekolah yang terjadi dimana masih banyak ditemukan kasus siswa dengan usia dini putus sekolah dikarenakan kesulitan biaya. PIP sangat dibutuhkan oleh siswasiswi yang berasal dari keluarga miskin, karena siswa-siswi yang berasal dari keluarga miskin sangat rentan akan terjadinya masalah putus sekolah pada usia dini. 
Hal ini disebabkan oleh keadaan perekonomian keluarga siswa yang kurang mendukung, sehingga kebanyakan siswa memutuskan untuk berhenti sekolah dan memilih untuk membantu keluarga dengan bekerja. Atas dasar masalah ini, pemerintah mengambil langkah upaya pemecahan masalah agar siswa yang berasal dari keluarga miskin dapat menyelesaikan sekolahnya dan melanjutkan pendidikan ke jenjang yang lebih tinggi. Pemerintah telah berusaha mewujudkan tujuan negara tersebut dengan Kartu Indonesia Pintar. Kartu Indonesia Pintar akan membuat semua anak usia sekolah di Indonesia mendapatkan kemudahan yang sama untuk mengenyam pendidikan. Cara mendapatkan Kartu Indonesia Pintar yaitu peserta didik mendaftar dengan cara membawa Kartu Keluarga Sejahtera (KKS) orang tuanya ke lembaga pendidikan terdekat (dinas pendidikan) atau bisa juga melapor ke sekolah tempat anak tersebut sekolah. Apabila siswa tersebut tidak memiliki KKS, orang tuanya dapat meminta Surat Keterangan Tidak Mampu (SKTM) dari RT/RW dan Cara mendapatkan Kartu Indonesia Pintar yaitu peserta didik mendaftar dengan cara membawa Kartu Keluarga Sejahtera (KKS) orang tuanya ke lembaga pendidikan terdekat (dinas pendidikan) atau bisa juga melapor ke sekolah tempat anak tersebut sekolah. Apabila siswa tersebut tidak memiliki KKS, orang tuanya dapat meminta Surat Keterangan Tidak Mampu (SKTM) dari RT/RW dan Kelurahan/Desa terlebih dahulu agar dapat melengkapi syarat pendaftaran. Setelah itu sekolah/madrasah mencatat data siswa calon penerima kartu indonesia pintar (KIP) untuk dikirim/diusulkan ke dinas pendidikan kabupaten/kota setempat. Dinas pendidikan kabupaten/kota mengirim data/rekapitulasi pengajuan calon penerima KIP ke kemndikbud. Sekolah yang berada dalam naungan kemendikbud wajib memasukan data calon penerima KIP dalam dapodik. Jika lulus, maka kemendikbud akan mengirimkan KIP kepada calon penerima KIP yang lolos seleksi.

Program Indonesia Pintar (PIP) melalui Kartu Indonesia Pintar (KIP) tampaknya menjadi sebuah alat Pemenuhan Hak Warga negara Di Bidang Pendidikan. Dengan Kartu Indonesia Pintar ini, Negara dapat dengan mudah untuk memenuhi hak warga negara untuk mendapatkan pendidikan. Selama tahun 2014 hingga 2019 Jumlah penerima Kartu Indonesia Pintar (KIP) meningkat signifikan. Jumlah penerima KIP pada 2014 hanya sekitar 7.950 .012 siswa. Kemudian pada tahun 2019 berjumlah 17.900.000 siswa. Melihat data ke belakang, pada tahun 2015, sebanyak 18.977.014 siswa menerimanya. Kemudian pada 2016, ada 19.221.903 siswa, pada 2017 ada 18.248.287 siswa, dan pada tahun 2018 ada 18.745 .047 siswa.

Anggaran Program Indonesia Pintar (PIP) atau KIP pada 2014 sebesar Rp 4,3 triliun, pada 2015 sebanyak Rp 9,7 triliun dan pada 2016 sebanyak 9,68 triliun. "Pada 2017, anggaran PIP sebanyak Rp 9,36 triliun dan pada 2018 sebanyak Rp9,71 triliun," kata Sekretaris Jenderal Kemendikbud Didik Suhardi, PhD (Kelana, 2019).

Besaran jumlah dana pada setiap tingkat pendidikan mendapat bantuan dana yang berbeda. Untuk tingkat Sekolah Dasar/ Madrasah Ibtidaiyah/ Paket A sebesar Rp 225.000,00 per semester atau Rp 450.000,00 pertahun. Tingkat Sekolah Menengah Pertama/ Madrasah Tsanawiyah/ Paket B sebesar Rp 375.000,00 per semester atau Rp 
750.000,00 per tahun. Sedangkan untuk tingkat Sekolah Menengah Atas/ Sekolah Menengah Kejuruan/ Madrasah Aliyah/ Paket C sebesar Rp 500.000,00 per semester atau Rp 1.000.000,00 per tahun. Pengalokasian dana bantuan ini ditujukan untuk mencukupi kebutuhan pendidikan siswa di luar biaya operasional sekolah, misalnya untuk membeli perlengkapan sekolah, biaya transportasi, uang saku, dan lain-lain. Berdasarkan konteks ini, membuktikan bahwa pendidikan merupakan medium tentang bagi upaya mengatasi masalah kemiskinan. Pemerintah perlu terus berupaya meningkatkan pemerataan dan perluasan akses pendidikan yang berfokus pada pendidikan dasar. Hal itu diyakini sebagai tali simpul untuk mengurangi benang kusut masalah kemiskinan. Upaya membangun pendidikan bermutu yang dimulai dari pendidikan dasar ini didasarkan pada dua pertimbangan penting. Pertama, pendidikan dasar akan melahirkan dan meningkatkan jumlah penduduk melek huruf. Bahwa kemiskinan dan pendidikan adalah dua aspek yang memiliki kaitan sangat erat apabila digabungkan dengan kesejahteraan yang ada di masyarakat (Herlina, 2014).

Dalam konteks tersebut, membuktikan bahwa pendidikan merupakan solusi mengatasi masalah kemiskinan. Pemerintah perlu terus berupaya meningkatkan pemerataan dan perluasan akses pendidikan yang layak. Negara harus mampu menyediakan layanan pendidikan kepada setiap warganya secara merata dan adil. Jika tidak, bangsa Indonesia akan menghadapi bencana sosial yang membuat kehidupan masyarakat semakin tidak sejahtera kehidupannya. Konsep peranan pendidikan dalam upaya pengentasan kemiskinan bukan sekedar sebagai isu belaka namun secara langsung dapat berfungsi sebagai kekuatan untuk mengurangi jumlah kemiskinan yang ada padat saat ini. Oleh karena itu perspektif program yang tepat dalam hal Ini adalah Program Indonesia Pintar dapat mengembangkan pilar-pilar penguatan program kegiatan pengentasan kemiskinan yang bersandar pada pentingnya peranan pendidikan sebagai pilar utama pembangunan.

\section{Kesimpulan}

Konsep Sustainable Development Goals (SDGs) pada point pertama mengatakan bawah No Poverty atau tanpa kemiskinan, tidak ada kemiskinan dalam bentuk apapun di seluruh dunia menjadi point prioritas yang bermakna bahwa seluruh dunia telah sepakat untuk meniadakan kemiskinan dalam bentuk apapun termasuk Indonesia. Indonesia mengimplementasikan pengentasan kemiskinan dengan salah satu cara adalah dengan program pendidikan yaitu Program Indonesia Pintar Melalui Kartu Indonesia Pintar. Konsep pengentasan kemiskinan melalui pendidikan sudah pernah sebelumnya di katakan oleh Jeffrey Sachs bahwa salah satu upaya pemberantasan kemiskinan yaitu dengan peningkatan human capital dalam hal pendidikan.

Program Indonesia Pintar (PIP) melalui Kartu Indonesia Pintar (KIP) oleh Presiden Joko Widodo menjadi cara pengentasan kemiskinan tampaknya berjalan cukup sukses hal tersebut dapat dilihat dari data BPS tahun 2015 sampai 2019 tentang angka kemiskinan dan angka partisipasi sekolah (APS) selama periode Joko Widodo menjabat. Langkah-langkah pemerataan dan perluasan akses pendidikan melalui 
Program Indonesia tersebut meskipun tidak berhubungan langsung dengan tingkat kesejahteraan seseorang, namun sebagian besar masyarakat miskin, pendidikan menjadi hak dasar mereka serta merupakan salah satu alat mobilitas vertikal terpenting dalam kehidupan.

Pendidikan menjadi investasi serta kesempatan untuk berkompetisi guna mendapatkan kesempatan memperoleh penghidupan yang lebih baik di masa depan dan turut terlibat dalam proses pembangunan. Dengan pendidikan yang terprogram baik dan menjangkau semua lapisan masyarakat secara tidak langsung Program Indonesia Pintar telah sukses menerapkan Sustainable Development Goals tidak hanya Goals pertama yaitu No Poverty, namun juga Goals ke 4 yaitu Quality Education. Oleh sebab itu, pendidikan menjadi Instrumen paling efektif untuk memotong mata rantai kemiskinan yang ada di Indonesia yang kita cintai ini.

\section{Tentang Penulis}

Ahmad Fajar Rahmatullah dan Ahmad Farhan Rahmatullah merupakan kakakadik yang sama-sama menempuh pendidikan sarjana di Universitas Muhammadiyah Yogyakarta. Ahmad Fajar Rahmatullah merupakan lulusan Sarjana Ilmu Pemerintahan. Sedangkan Ahmad Farhan Rahmatullah merupakan mahasiswa Ilmu Hukum Universitas Muhammadiyah Yogyakarta angkatan 2020.

\section{Ucapan Terimakasih}

Terima Kasih Kepada diri sendiri dan Allah Swt yang memberikan akal pikiran.

\section{References}

Amaliah, D. (2015). Pengaruh Partisipasi Pendidikan Terhadap Persentase Penduduk Miskin. Faktor Jurnal Ilmiah Kependidikan, 2(3), 231-239.

Badan Pusat Statistik. (n.d.-a). Angka Partisipasi Sekolah. Badan Pusat Statistik. https://www.bps.go.id/linkTableDinamis/view/id/1054

Badan Pusat Statistik. (n.d.-b). Persentase Penduduk Miskin Menurut provinsi Kemiskinan 2007-2019. Badan Pusat Statistik.

https://www.bps.go.id/dynamictable/2016/08/18/1219/persentase-pendudukmiskin-menurut-provinsi-2007---2019.html

Cinelli, M., Coles, S., \& Kirwan, K. (2014). Analysis of the potentials of multi criteria decision analysis methods to conduct sustainability assessment. Ecological Indikators, 46, 138-148.

Crespo Cuaresma, J., Fengler, W., Kharas, H., Bekhtiar, K., Brottrager, M., \& Hofer, M. (2018). Will the Sustainable Development Goals be fulfilled? Assessing present and future global poverty. Palgrave Communications, 4(1).

https://doi.org/10.1057/s41599-018-0083-y 
Erlinda, N. (2016). KEBIJAKAN PEMBANGUNAN WILAYAH BERKELANJUTAN DI PROVINSI JAMBI MELALUI PENDEKATAN MODEL FLAG. Jurnal Ekonomi $\mathcal{E}$ Kebijakan Publik, 7(1), 1-14.

Fauzi, A., \& Oxtavianus, A. (2014). Pengukuran Pembangunan Berkelanjutan di Indonesia. In MIMBAR, Jurnal Sosial dan Pembangunan (Vol. 30, Issue 1, p. 42). https://doi.org/10.29313/mimbar.v30i1.445

Florini, A., \& Pauli, M. (2018). Collaborative governance for the Sustainable Development Goals. Asia and the Pacific Policy Studies, 5(3), 583-598. https://doi.org/10.1002/app5.252

Grigss, D. (2013). Sustainable developmnet goals for people and planet. Nature, 495(7441), 305-307.

Herlina, E. (2014). Pendidikan dan Pelatihan dalam Meningkatkan Model Kerjasama Usaha Menengah Kecil dan Mikro Dengan Usaha Besar di Kecamatan Cikoneng Kabupaten Ciamis. Ekonologi, 1(April), 71-81.

Hermawan, I. (2019). Metodologi Penelitian Pendidikan (Kualitatif, Kuantitatif Dan Mixed Method). Hidayatul Quran.

Jayanti, E. (2017). Hubungan Pertumbuhan Penduduk Dengan Tujuan Pembangunan Berkelanjutan Di Sumatera. Jurnal Ekonomi Dan Kebijakan Publik Indonesia, 4(2), 136155.

Jonaidi, A. (2012). ANALISIS PERTUMBUHAN EKONOMI DAN KEMISKINAN DI INDONESIA. Kajian Ekonomi, 1(April), 140-164.

Kates, R. W., Parris, T. M., \& Leiserowitz, A. A. (2005). What is sustainable development? Goals, indicators, values, and practice. Environment, 47(3), 8-21. https:// doi.org/10.1080/00139157.2005.10524444

Kelana, N. S. (2019). No TitleTengok, Data Penerima KIP Mulai Tahun 2014 hingga Sekarang. Siedoo:Mengupas Pendidikan Dari Pelosok Negeri.

https:/ / siedoo.com/ berita-18046-tengok-data-penerima-kip-mulai-tahun-2014hingga-sekarang/

Le Blanc, D. (2015). Towards Integration at Last? The Sustainable Development Goals as a Network of Targets. Sustainable Development, 23(3), 176-187.

https://doi.org/10.1002/sd.1582

Nababan, Y. J., Syaukat, Y., Juanda, B., \& Sutomo, S. (2014). TANTANGAN BAGI PEMBANGUNAN BERKELANJUTAN DI KALIMANTAN TIMUR: MENUJU INCLUSIVE GREEN ECONOMY. Masyarakat Indonesia, 40(2), 211-228.

Nawawi. (2015). Metode Penelitian Bidang Sosial. UGM Press.

Nazir, M. (2013). Metode Penelitian. Ghalia Indonesia.

Niken Pratiwi, Dwi Budi Santosa, K. A. (2018). Analisis Implementasi Pembangunan Berkelanjutan Di Jawa Timur. Jiep, 18(1), 1-13.

Nur, F. (2014). PENGENTASAN KEMISKINAN MELALUI PENDEKATAN KEWIRAUSAHAAN SOSIAL. Jurnal Ekonomi Dan Pembangunan, 22(1), 55. 
Poveda, C. A., \& Lipsett, M. G. (2011). A reviewof sustainability assessment andsustainability/environmental rating systems and credit weighting tools. Journal Sustainable Development, 4(6), 36-52.

Raharjo, S. T. R. I. (2015). SUSTAINABLE DEVELOPMENT GOALS ( SDGs ). 0042, 159167.

Rahmatullah, A. F., Purnomo, E. P., \& Kasiwi, A. N. (2020). RENCANA PEMBANGUNAN JANGKA MENENGAH DAERAH KOTA JAMBI 2013-2018 SUDAHKAH MEMASUKKAN PENTINGNYA KONSEP SMART CITY. Moderat: Jurnal Ilmiah Ilmu Pemerintahan, 6(1), 125-134.

Rohaeni, N. E., \& Saryono, O. (2018). Implementasi Kebijakan Program Indonesia Pintar ( PIP ) Melalui Kartu Indonesia Pintar ( KIP ) dalam Upaya Pemerataan Pendidikan. Journal of Education Management and Administration Review, 2(1), 1-12.

Sachs, J. D. (2005). The End of Poverty: Economic Possibilities for Our Time. Penguin Press.

Sachs, J. D. (2012). From millennium development goals to sustainable development goals. The Lancet, 379(9832), 2206-2211. https:/ / doi.org/10.1016/S01406736(12)60685-0

Shmelev, S. E., \& Labajos, B. (2009). Dynamic multidimensional assessment of sustainability at the macro level: The case of Austrian. Ecological Economic, 68, 2.5602.573 .

Sugiyono. (2013). Metode penelitian kuantitatif, kualitatif dan RED. Alfabeta.

Sutopo, A., Arthati, D. F., \& Rahmi, U. A. (2014). Kajian Indikator Sustainable Development Goals ( SDGs ).

United Nation. (2015). Transforming our World: The 2030 Agenda for Sus- tainable Development. https://goo.gl/RsCfjC

Ustama, D. D. (2010). Peranan Pendidikan Dalam Pengentasan Kemiskinan. Dialogue, $6(1), 1-12$.

Wahyuningsih. (2017). MILLENIUM DEVELOMPENT GOALS (MDGS) DAN SUSTAINABLE DEVELOPMENT GOALS (SDGS) DALAM KESEJAHTERAAN SOSIAL. Jurnal Bisnis Dan Manajemen, 11(3), 390-399.

Wibisana, A. G. (2017). Pembangungan Berkelanjutan: Status Hukum Dan Pemaknaannya. Jurnal Hukum \& Pembangunan, 43(1), 54. https:// doi.org/10.21143/jhp.vol43.no1.1503 